\title{
$\beta$-Glucan Synthesis and Glucan Synthase Activities during Early Stages of Cell Wall Regeneration by Protoplasts from Saprolegnia monoica
}

\author{
By VINCENT GIRARD, ANDRÉ CAPELLANO AND MICHEL FÈVRE* \\ Laboratoire de Mycologie associé au CNRS et CMEABG, Université Claude Bernard, \\ Bâtiment 405, 43 Bd du 11 Novembre 1918, 69622 Villeurbanne Cédex, France
}

(Received 21 February 1984; revised 26 April 1984)

\begin{abstract}
Protoplasts isolated from Saprolegnia monoica were used to study $\beta$-glucan synthases and polysaccharide synthesis during wall regeneration. $(1 \rightarrow 4)-\beta$ - and $(1 \rightarrow 3)$ - $\beta$-glucan synthase activities of plasma membranes and internal membranes increased during regeneration. Within minutes of cultivation, protoplasts transferred radioactivity from $\left[{ }^{14} \mathrm{C}\right]$ glucose to cellulose and other cell wall polymers. UDP $\left[{ }^{14} \mathrm{C}\right]$ glucose did not serve as substrate. Cellulose microfibrils were produced from the beginning of regeneration. The early phases of regeneration are realized by plasma membrane enzymes having remained intact during protoplast isolation and independently of the Golgi apparatus.
\end{abstract}

\section{INTRODUCTION}

The hyphal wall of Oomycetes contains cellulose and $(1 \rightarrow 3)-\beta-/(1 \rightarrow 6)-\beta$-glucans (Burnett, 1976). We have previously shown that cell-free extracts of Saprolegnia monoica can produce in vitro $(1 \rightarrow 4)-\beta$ - and/or $(1 \rightarrow 3)-\beta$-glucans from UDPglucose (Fèvre \& Rougier, 1981). The synthases are associated with internal membranes and particularly with the Golgi apparatus (Fèvre, 1979 $a$; Fèvre \& Rougier, 1981). Recently, by using Con-A coated protoplasts, we have isolated plasma membranes and shown that both synthase activities are associated with the plasmalemma (Girard \& Fèvre, 1984a). In this study, cell wall regeneration by protoplasts was used as a system to study the activity of the plasma membrane-bound synthases and the biosynthesis of wall components. While numerous studies have described patterns of protoplast regeneration and reversion (for reviews see Peberdy, 1979; Wessels et al., 1976), to our knowledge the activity of $\beta$-glucan synthases during regeneration of fungal protoplasts has not been investigated until now. The study was limited to the beginning of regeneration, i.e. the phase of cell wall synthesis around the spherical cell, in order to avoid the processes involved in the reversion of protoplasts to normal hyphae.

\section{METHODS}

Cultural methods. Saprolegnia monoica Pringsheim (no. 53967 Dick) obtained from CBS, Baarn, The Netherlands, was maintained on a wheat flour medium. Mycelia were grown in liquid medium (Machlis, 1953) at $23^{\circ} \mathrm{C}$ for $48 \mathrm{~h}$ and harvested by filtration.

Protoplast production. Mycelia ( $48 \mathrm{~h}$ old) were converted to protoplasts during $2 \mathrm{~h}$ incubation in a lytic medium:

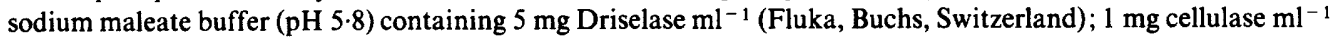
(Fluka); $120 \mathrm{~mm}$-phenylmethylsulphonyl fluoride and 0.5 M-sorbitol as stabilizer (Gaugy \& Fèvre, 1982). Protoplasts were separated from mycelia by filtration through bolting cloth $(70 \mu \mathrm{m})$, centrifuged at $700 \mathrm{~g}$ for 10 min, washed twice with the osmotic medium, and then resuspended at a final concentration of $10^{6}$ protoplasts $\mathrm{ml}^{-1}$.

Preparation of the plasma membrane fraction $(P M F)$ and the internal membrane fraction $(I M F)$. Protoplasts were

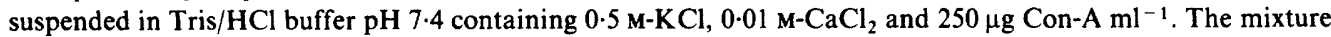
was maintained at $4{ }^{\circ} \mathrm{C}$ for $30 \mathrm{~min}$. Non-fixed Con-A was eliminated by dilution of the protoplast suspension with

Abbreviations: Con-A, concanavalin A; IMF, internal membrane fraction; PMF, plasma membrane fraction. 
buffer and then centrifuged. The pellet was washed twice with buffer, and then resuspended in $10 \mathrm{mM}-\mathrm{Tris} / \mathrm{HCl}$ buffer $\mathrm{pH} 7.4$ containing $0.1 \mathrm{M}-\mathrm{KCl}$ and $0.01 \mathrm{M}-\mathrm{CaCl}_{2}$. The suspension was homogenized using a Virtis homogenizer for three periods of $30 \mathrm{~s}$. Alternatively, protoplasts were broken by slow passage through a syringe and then through a glass homogenizer with a Teflon pestle. The PMF was collected by centrifugation of the lysate at $500 \mathrm{~g}$ for $10 \mathrm{~min}$. The supernatant was centrifuged at $48000 \mathrm{~g}$ for $30 \mathrm{~min}$ to pellet the IMF.

Enzyme assays. When enzymes were assayed for $(1 \rightarrow 4)-\beta$-polysaccharide synthesis, the complete mixture (total volume $370 \mu \mathrm{l})$ contained $0.3 \mathrm{nmol}$ UDP $\left[{ }^{14} \mathrm{C}\right.$ glucose $\left(7.4 \mathrm{MBq} \mu \mathrm{mol}^{-1}\right) 0 \cdot 1 \mu \mathrm{mol}$ dithiothreitol, $2 \mu \mathrm{mol}$ cellobiose, $5.5 \mu \mathrm{mol} \mathrm{MgCl}_{2}, 25 \mathrm{mM}$-PIPES/Tris buffer pH 6.0 and $100 \mu \mathrm{l}$ freshly isolated enzymes. When enzymes were assayed for $(1 \rightarrow 3)$ - $\beta$-glucan synthesis, $\mathrm{MgCl}_{2}$ was omitted and a higher substrate level was provided (400 nmol UDP $\left[{ }^{12} \mathrm{C}\right.$ lglucose). Mixtures were incubated at $27^{\circ} \mathrm{C}$ for $30 \mathrm{~min}$. Reactions were terminated by heating the tubes for $2 \mathrm{~min}$ in a boiling bath or by addition of $2 \mathrm{ml}$ ethanol and precipitation overnight at $-20^{\circ} \mathrm{C}$. After addition of powdered cellulose (10 to $20 \mathrm{mg}$ ), mixtures were filtered through glass fibre filters (Whatman GF/C $2.4 \mathrm{~cm})$. Residues on the filter were washed with $40 \mathrm{ml}$ water, $20 \mathrm{ml}$ chloroform/methanol $(2: 1, \mathrm{v} / \mathrm{v})$ and $40 \mathrm{ml}$ ethanol. Radioactivity of filters was determined with an Intertechnique SL 33 scintillation counter using a PPO/POPOP/toluene scintillation mixture.

Protoplast regeneration. Protoplasts were suspended in the culture medium of Machlis (1953) containing 0.5 Msorbitol, $0 \cdot 1 \%(\mathrm{w} / \mathrm{v})$ glucose and $1 \mu \mathrm{Ci}\left[{ }^{14} \mathrm{C}\right] \mathrm{glucose} \mathrm{ml}^{-1}\left(240 \mathrm{mCi} \mathrm{nmol}{ }^{-1}\right)$. The suspension $\left(1\right.$ to $5 \times 10^{6}$ protoplasts $\mathrm{ml}^{-1}$ ) was incubated at $24^{\circ} \mathrm{C}$ in a shaking incubator. Samples were taken at intervals and the regeneration process was stopped by adding 2 vols ethanol. Suspensions were precipitated overnight at $-20^{\circ} \mathrm{C}$.

Isolation of polysaccharide fractions. After ethanol precipitation, protoplasts were collected by centrifugation, washed with water, chloroform/methanol $(2: 1, v / v)$ and ethanol; the remaining material represented the total cell wall polysaccharides of regenerating protoplasts.

The cellulose fraction was isolated according to Updegraff (1969). After centrifugation, ethanol-precipitated protoplasts were resuspended in acetic/nitric acid reagent $(80 \%$ acetic acid/nitric acid; $10: 1, \mathrm{v} / \mathrm{v})$ and placed in a boiling water bath for $30 \mathrm{~min}$. Non-hydrolysable material, representing the cellulose fraction of regenerated cell walls, was collected by filtration. Radioactivity was determined as described above.

Electron microscopy. Protoplasts were fixed for $1 \mathrm{~h}$ by $3 \%(\mathrm{v} / \mathrm{v})$ glutaraldehyde in the culture medium. After being washed, protoplasts were post-fixed with $2 \% \mathrm{OsO}_{4}$ for $30 \mathrm{~min}$, dehydrated in a graded series of increasing ethanol concentration and embedded in Epon. Thin sections were cut with diamond knives on an ultramicrotome, mounted on collodion-coated grids and stained with uranyl acetate followed by alkaline lead citrate. Cell walls of regenerating protoplasts treated with Updegraff reagent (Updegraff, 1969) were deposited on collodion-coated grids, shadowed with $\mathrm{Au} / \mathrm{Pd}$. Observations and photographs were made by using either Hitachi $\mathrm{HU} 12 \mathrm{~A}$ or Philips EM 300 electron microscopes.

Autoradiography. Protoplasts were incubated in liquid medium containing $30 \mu \mathrm{Ci}\left[{ }^{3} \mathrm{H}\right] \mathrm{glucose} \mathrm{ml}^{-1}$ $\left(2.5 \mathrm{mCi} \mathrm{mmol}^{-1}\right)$. After labelling $(5 \mathrm{~min})$, protoplasts were rinsed with the non-radioactive nutritive medium and then fixed in glutaraldehyde $(2 \%, \mathrm{v} / \mathrm{v})$. Protoplasts were mounted on gelatin-covered slides and then coated by stripping autoradiographic film (Kodak AR10). Slides were developed (Kodak D19) after 5 d exposure.

\section{RESULTS}

\section{Cytological aspects of protoplast regeneration}

Electron microscopy of freshly prepared protoplasts showed that the cell surface was devoid of residual cell wall material. The number of nuclei per protoplast was variable and mitochondria were abundant. An important characteristic of these protoplasts was the absence of the typical Golgi apparatus and the presence of few profiles of endoplasmic reticulum. Most protoplasts contained numerous vacuoles of different sizes which appeared to be empty or containing microfibrillar inclusions. After $6 \mathrm{~h}$ regeneration, the ultrastructure of the cell content of regenerating protoplasts was not modified and was comparable to that of freshly prepared protoplasts. Vacuoles were numerous, endoplasmic reticulum profiles were rare and a Golgi apparatus was absent. The cell wall produced during regeneration appeared uniform in its structure and thickness and was loosely organized. (Fig. 1).

Light microscopy autoradiography of protoplasts incubated for $5 \mathrm{~min}$ in $\left[{ }^{3} \mathrm{H}\right]$ glucose $\left(30 \mu \mathrm{Ci} \mathrm{ml}{ }^{-1}\right)$ nutritive medium after 0 or $5 \mathrm{~h}$ regeneration showed that cell wall synthesis occurred over the whole cell surface. Some protoplasts were devoid of radioactivity but 80 to $90 \%$ of the protoplasts were capable of incorporating radioactive glucose into cell walls (Fig. 2). However, a great difference in intensity of glucose incorporation occurred among these protoplasts. Some were very active, while others were weakly active. This heterogeneity in 

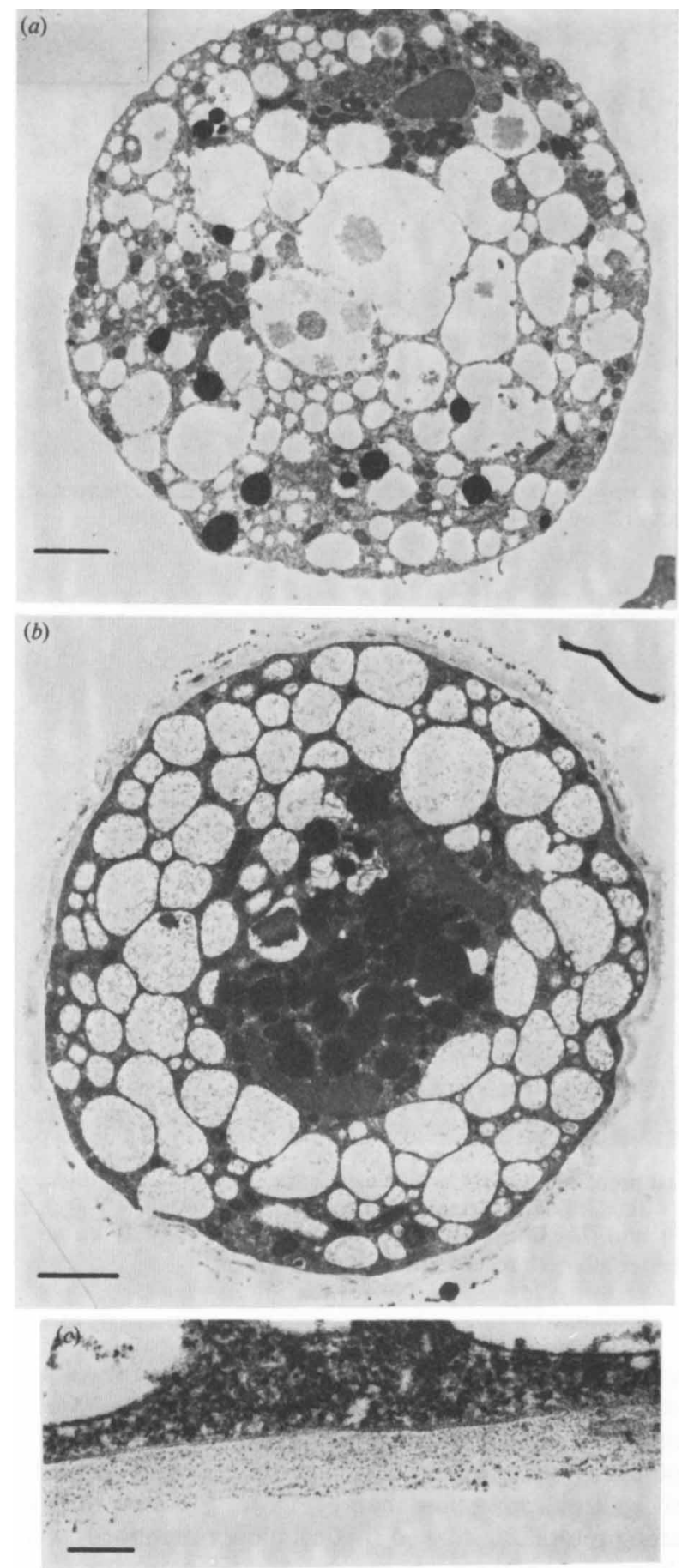

Fig. 1. Electron micrographs of protoplasts of Saprolegnia after $0 \mathrm{~h}(a)$ and $5 \mathrm{~h}(b)$ regeneration; bars, $2 \mu \mathrm{m}$. The cell wall was uniformly deposited around the protoplast and appeared homogeneous $(c)$; bar, $0 \cdot 2 \mu \mathrm{m}$. 


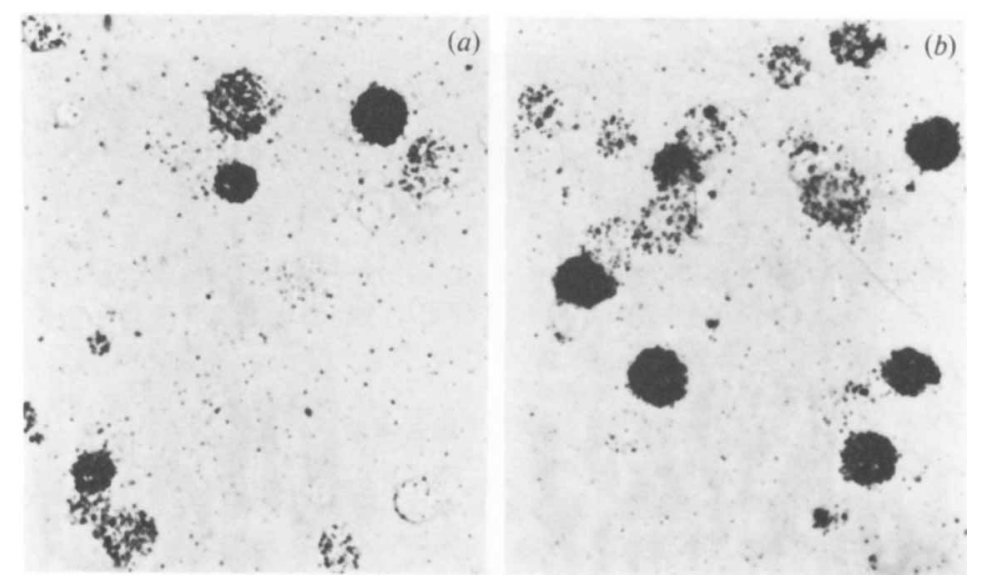

Fig. 2. Light microscopy autoradiography of regenerating protoplasts. Protoplasts were incubated for $5 \mathrm{~min}$ in $\left[{ }^{3} \mathrm{H}\right]$ glucose $\left(30 \mu \mathrm{Ci} \mathrm{ml}{ }^{-1}\right)$ after $0 \mathrm{~h}(a)$ or $5 \mathrm{~h}(b)$ regeneration.
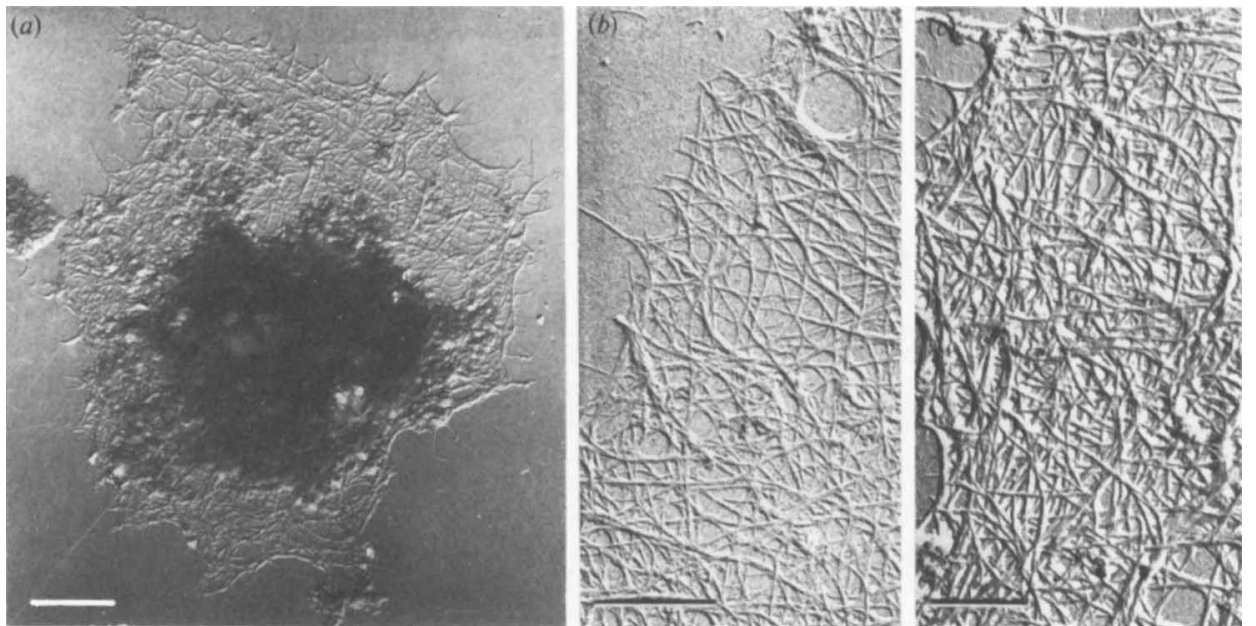

Fig. 3. Shadow-cast preparation of the cellulose microfibrillar network synthesized by a regenerating protoplast $(a)$; bar $1 \mu \mathrm{m}$. Cellulose was isolated after extraction of other polysaccharides by acetic/nitric acid $\left(100^{\circ} \mathrm{C}\right.$ for $\left.30 \mathrm{~min}\right)$. The microfibrillar net of cellulose, clearly visible after $2 \mathrm{~h}$ regeneration $(b)$, became slightly denser after $6 \mathrm{~h}$ regeneration $(c)$; bars $0.5 \mu \mathrm{m}$.

protoplasts might reflect the difference of their origin from the fungal hyphae. Growing zones (hyphal tips) gave very active protoplasts while subapical zones gave protoplasts that were weakly active or not at all active (Girard \& Fèvre, 1984b).

Regenerating protoplasts were treated with acetic/nitric acid reagent (Updegraff, 1969) in order to remove cell wall glucans other than cellulose. Electron microscopy of shadow-cast preparations of treated protoplasts showed that cellulose microfibrils were clearly visible after $2 \mathrm{~h}$ regeneration. The microfibrillar net became slightly denser after $6 \mathrm{~h}$ regeneration (Fig. 3). There was no indication of any orientation of the fibrils at this time.

\section{$\beta$-Glucan synthase activities during cell wall regeneration}

Protoplasts incubated in a nutritive medium were collected at different times during wall regeneration, washed, labelled with exogenous Con-A and then homogenized. Glucan synthase 


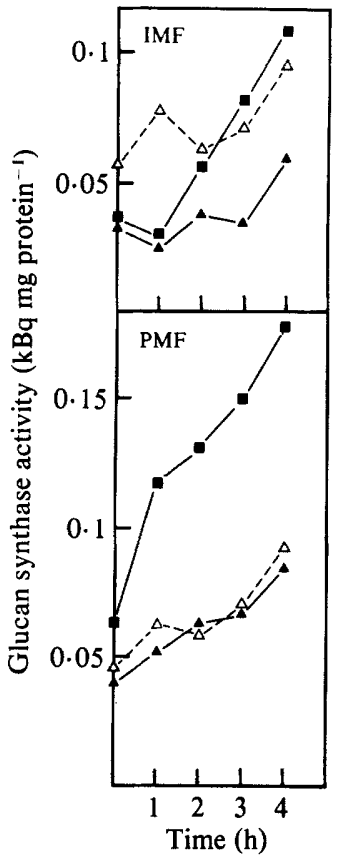

Fig. 4

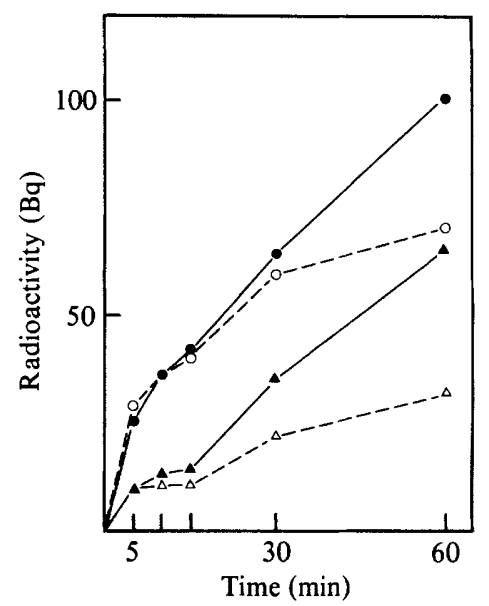

Fig. 5

Fig. 4. Glucan synthase activities of protoplasts during regeneration. Plasma membrane fraction (PMF) and internal membrane fraction (IMF) were isolated by centrifugation of protoplast homogenates. $\square,(1 \rightarrow 4)-\beta$-Glucan synthase; $(1 \rightarrow 3)$ - $\beta$-glucan synthase assayed in the absence $(\Delta)$ or presence $(\triangle)$ of trypsin $\left(500 \mu \mathrm{g} \mathrm{ml}^{-1}\right)$.

Fig. 5. Incorporation of radioactive glucose into cell wall polysaccharides during incubation of protoplasts in UDP $\left[{ }^{14} \mathrm{C}\right]$ glucose. Protoplasts were incubated in conditions of $(1 \rightarrow 4)-\beta$-glucan synthesis $(\Theta, \bigcirc)$ or $(1 \rightarrow 3)$ - $\beta$-glucan synthesis $(\Delta, \Delta)$ in the absence $(\Theta, \Delta)$ or presence $(O, \Delta)$ of unlabelled glucose $(1 \%, w / v)$.

activities were measured in a PMF and an IMF isolated by centrifugation of Con-A labelled protoplast homogenates (Girard \& Fèvre, 1984a). $(1 \rightarrow 3)$ - $\beta$-Glucan synthase specific activity of the IMF increased slowly and the addition of trypsin, which stimulates this enzyme activity (Fèvre, $1979 b$ ), revealed a latent enzyme component which also increased during wall regeneration (Fig. 4). ( $1 \rightarrow 3)$ - $\beta$-Glucan synthase activity of the PMF also increased slowly and was not significantly stimulated by trypsin, indicating that the enzymes were in an active form in this fraction. $(1 \rightarrow 4)-\beta$-Glucan synthase activity was higher in the PMF than in the IMF and increased rapidly in both fractions (Fig. 4).

\section{Incubation of protoplasts in the presence of $U D P\left[{ }^{14} \mathrm{Clglucose}\right.$}

Freshly isolated protoplasts were incubated in the presence of radioactive UDPglucose. At different times of incubation, samples were withdrawn and radioactive glucose incorporation into cell wall polysaccharides was measured. When incubated in the conditions for $(1 \rightarrow 3)-\beta$ - or $(1 \rightarrow 4)$ - $\beta$-glucan synthase assays, protoplasts incorporated glucose from UDPglucose. However, this incorporation was progressively inhibited when unlabelled glucose was added to the incubation mixtures (Fig. 5). This could indicate a saturation of endogenous UDP $\left[{ }^{12} \mathrm{C}\right]$ glucose by glucose or that part of the $\left[{ }^{14} \mathrm{C}\right]$ glucose released by UDPglucose degradation was used as the substrate. The presence of respiratory inhibitors such as KCN (1 mM) or DNP (0.5 mM) strongly reduced glucose incorporation from UDPglucose in the absence of exogenous $\left[{ }^{12} \mathrm{C}\right]$ glucose, confirming that UDPglucose was not the only substrate (data not shown). The presence of 'leaky' protoplasts in the preparations is probably responsible for the low incorporation from UDPglucose observed at the beginning of regeneration. 


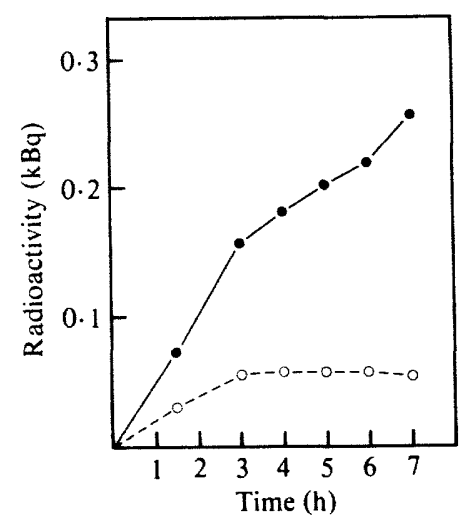

Fig. 6

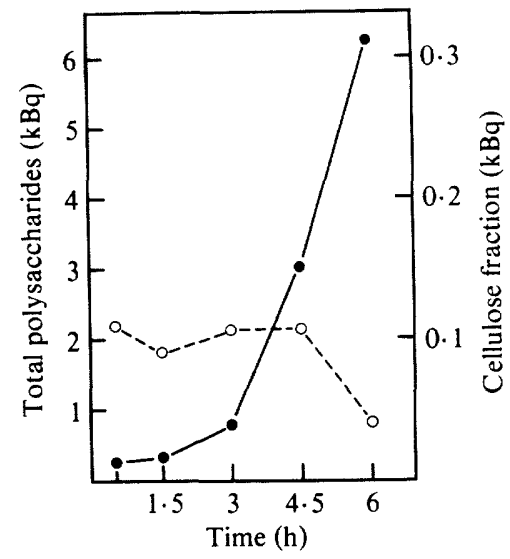

Fig. 7

Fig. 6. Incorporation of $\left[{ }^{14} \mathrm{C}\right] g l u c o s e$ into cell wall polysaccharides during regeneration of protoplasts in liquid medium containing $1 \mu \mathrm{Ci}\left[{ }^{14} \mathrm{C}\right]$ glucose $\mathrm{ml}^{-1}$. $O$, Total wall polysaccharides; $O$, cellulose fraction insoluble in acetic/nitric acid.

Fig. $7 .\left[{ }^{1+} \mathrm{C}\right]$ Glucose incorporation into cell wall polysaccharides measured at different times of regeneration. Protoplasts were suspended in a liquid regeneration medium. Samples were taken at intervals and incubated for $1 \mathrm{~h}$ in the presence of radioactive glucose $\left.(1 \mu \mathrm{Ci} \mathrm{ml})^{-1}\right)$. Radioactivity in total cell wall polysaccharides; $O$, radioactivity in cellulose fraction insoluble in acetic/nitric acid.

\section{$\left[{ }^{14} \mathrm{C}\right]$ Glucose incorporation in cell wall polysaccharides}

Protoplasts were regenerated in a nutritive medium containing $1 \mu \mathrm{Ci}$ radioactive glucose $\mathrm{ml}^{-1}$. Glucose incorporation in the total cell wall polysaccharides and in the cellulose fraction (i.e. polymers insoluble in acetic/nitric acid reagent) was measured during the course of regeneration. Within minutes radioactivity from $\left[{ }^{14} \mathrm{C}\right]$ glucose was transferred to cell wall glucans. While total polysaccharide synthesis continued during $7 \mathrm{~h}$ regeneration, the production of the cellulosic fraction ceased after $3 \mathrm{~h}$ (Fig. 6). Essentially, no glucans were secreted into the culture medium, as measured by polysaccharide precipitation of the medium with 2 vols ethanol.

The capacity of protoplasts to produce cell wall polysaccharides during regeneration was also estimated by incubating protoplasts collected at different times from a non-radioactive regenerating medium in $1 \mu \mathrm{Ci}\left[{ }^{14} \mathrm{C}\right]$ glucose $\mathrm{ml}^{-1}$ for $1 \mathrm{~h}$. The capacity at different periods of regeneration to produce total cell wall glucans started slowly and then increased rapidly: after $4.5 \mathrm{~h}$ regeneration, protoplasts incorporated 10 times more glucose than protoplasts withdrawn after $1.5 \mathrm{~h}$ regeneration. In contrast, the capacity to produce cellulose was more or less constant during this period of regeneration (Fig. 7).

\section{DISCUSSION}

The development of protoplasts in culture provides a simple system to examine the activity of the cell wall synthesizing enzymes of the plasma membrane. The present study was limited to the early stages of rebuilding of a new wall on the naked cell in order to avoid complications by the events which take place during the transition to normal hyphal development.

Immediately after their isolation, 80 to $90 \%$ of the protoplasts were capable of producing a cell wall, as revealed by autoradiography. However, protoplasts exhibited a heterogeneity in the intensity of regeneration which is probably related to their zone of origin from the hyphae and, consequently, to their supply of polysaccharide synthases. We have, moreover, previously shown that $\beta$-glucan synthases are mainly located in the apical zone (Girard $\&$ Fèvre, 1984b).

Cell wall regeneration is characterized by the synthesis of a network of microfibrils of cellulose, insoluble in acetic/nitric acid reagent (Updegraff, 1969; Klein et al., 1981). The 
cellulose microfibrillar net deposited around the spherical cells and clearly visible after $2 \mathrm{~h}$ regeneration becomes slightly denser after $6 \mathrm{~h}$ regeneration while the size of microfibrils remains unchanged.

Electron microscopy observations suggested that the early stages of regeneration (up to $6 \mathrm{~h}$ ) are independent of the endomembrane system. From numerous observations made on different samples, we have no evidence for the restoration of a vesicular transport system through the Golgi flow comparable to those existing at the hyphal apex (Fèvre, 1979a). Cell wall synthesis at the beginning of regeneration is probably due to the enzymes present at the cell surface, the enzymic machinery involved in hyphal cell wall growth being kept intact during protoplast conversion of the mycelium.

The cell wall polysaccharide synthase activities of protoplast extracts increased during the course of cell wall regeneration. $(1 \rightarrow 4)-\beta$-Glucan synthases of the plasma membranes and of the internal membranes increased rapidly from the beginning of regeneration. In contrast, $(1 \rightarrow 3)-\beta$ glucan synthase activities increased more slowly with the activities bound to internal membranes, exhibiting a lag phase of $3 \mathrm{~h}$.

Regenerating protoplasts cannot use external UDPglucose as a substrate. The little incorporation observed was due in part to the utilization of glucose released by degradation of the substrate and also probably to the presence of 'leaky' protoplasts in the preparations. These observations indicate that the substrate binding site of plasma membrane glucan synthase faces the inside of the cell and confirm the transmembrane orientation of these synthases in the plasma membrane (Girard \& Fèvre, 1984a).

Cell wall synthesis and cellulose production were followed by measuring the rate of incorporation of external $\left[{ }^{14} \mathrm{C}\right]$ glucose. The rate of cell wall synthesis was approximately linear over 6 to $7 \mathrm{~h}$ while glucose incorporation into cellulose reached a plateau after $3 \mathrm{~h}$. However, the capacity to produce cell wall glucans, estimated by incorporation of glucose during $1 \mathrm{~h}$ at different times after regeneration began, indicated that protoplasts were still capable of producing cellulose at a constant rate. On the other hand, the capacity to produce other cell wall polysaccharides increased rapidly. As in other studies (Wessels et al., 1976; Peberdy, 1979), wall biogenesis by protoplasts from Saprolegnia commences with the deposition of a microfibrillar skeleton with the subsequent deposition of other polysaccharides.

Our results indicate that cellulose and other cell wall polysaccharides are produced by plasma membrane enzymes kept active during protoplast formation. Cell wall synthesis starts immediately after the onset of cultivation and does not seem to involve Golgi participation during the early stages of regeneration.

The authors would like to thank Dr G. Maclachlan, McGill University, Montreal, Canada, for critically reading the manuscript. This research was supported by the Direction de la Recherche-Aide à la Recherche Universitaire-Biologie 1982 and 1983.

\section{REFERENCES}

BURNETT, J. H. (1976). Fundamentals of Mycology, 2nd edn. London: Edward Arnold.

FÈVre, M. $(1979 a)$. Glucanases, glucan synthases and wall growth in Saprolegnia monoica. In Fungal Walls and Hyphal Growth, pp. 225-263. Edited by J. H. Burnett \& A. P. J. Trinci. Cambridge: Cambridge University Press.

FÈvre, M. (1979b). Digitonin solubilization and protease stimulation of $\beta$-glucan synthetases of Saprolegnia. Zeitschrift für Pflanzenphysiologie 95, 129-140.

FÈvre, M. \& Rougier, M. (1981). $\beta 1-3$ and $\beta 1-4$ glucan synthesis by membrane fractions from the fungus Saprolegnia. Planta 151, 232-241.

Gaugy, D. \& FĖvre, M. (1982). Protoplast production from Saprolegnia monoica, Microbios 34, 89-98.
Girard, D. \& FÈvre, M. (1984a). $\beta 1-4$ and $\beta 1-3$ glucan synthetases are associated with the plasma membrane of the fungus Saprolegnia. Planta 160 , $400-406$.

GIRARD, D. \& FÈVRE, M. (1984b). Distribution of $(1 \rightarrow 3)$ - $\beta$ - and $(1 \rightarrow 4)$ - $\beta$-glucan synthases along the hyphae of Saprolegnia. Journal of General Microbiology 130, 1557-1562.

Klein, A. S., Montezinos, D. \& Delmer, D. P. (1981). Cellulose and $1 \rightarrow 3 \beta$ glucan synthesis during the early stages of wall regeneration in soybean protoplasts. Planta 152, 105-114.

MACHLIS, L. (1953). Growth and nutrition of watermolds in the subgenus Euallomyces. II. Optimal composition of the minimal medium. American Journal of Botany 40, 449-460. 
Peberdy, J. F. (1979). Wall biogenesis by protoplasts. In Fungal Walls and Hyphal Growth, pp. 49-70. Edited by J. H. Burnett \& A. P. J. Trinci. Cambridge: Cambridge University Press.

UPDEGRAFF, D. M. (1969). Semi-micro determination of cellulose in biological materials. Analytical Biochemistry 32, 420-424.
WESSELS, J. G. H., VALK, P. VAN DER \& VRIES, O. M. H. DE. (1976). Wall synthesis by fungal protoplasts. In Microbial and Plant Protoplasts, pp. 267-281. Edited by J. F. Peberdy, A. H. Rose, H. J.

Rogers \& C. C. Cocking. London: Academic Press. 